\title{
Heat treatment of cottonseed to increase its value as a dairy supplement
}

\author{
LD Satter, TR Dhiman, JT Hsu \\ US Dairy Forage Research Center, USDA, Agricultural Research Service, Madison, Wisconsin 53706, USA
}

The objective of this experimentation was to identify the optimum temperature to heat treat cottonseed for the purpose of improving protein utilization, and to measure potential milk production response to feeding of optimally heated cottonseed. Linted cottonseed was roasted to $134,141,150,155,159,176$ or $210^{\circ} \mathrm{C}$ and cooled immediately or held for 30 minutes at the elevated temperature before cooling. Available lysine, measured by the dinitrofluorobenzene method, decreased rapidly at temperatures above $159^{\circ} \mathrm{C}$. Maximum post ruminal available lysine, the product of lysine availability and ruminally undegraded protein (determined by the in situ method) was achieved when cottonseed was heated to 141 or $150^{\circ} \mathrm{C}$ and held without cooling for 30 minutes.

In another study, delinted coltonseed (unheated control, and the following cottonseed treatments with 30 minutes holding time: $136,146,156$ and $166^{\circ} \mathrm{C}$ ) were utilized in a heifer feeding study and a lactation trial, both using a double $5 \times 5$ Latin square design. Blood plasma branched-chain amino acids, used as an indicator of protein absorption from the gut, plateaued with the cottonseed heated to $146^{\circ} \mathrm{C}$. Cottonseed heated to this temperature also supported the highest milk yield of cows, with the unheated, 136, 146, 156 and $166^{\circ} \mathrm{C}$ treatments resulting in $36.9^{\mathrm{b}}, 36.7^{\mathrm{b}}$, $38.2^{\mathrm{a}}, 37.0^{\mathrm{ab}}$, and $35.8^{\mathrm{b}} \mathrm{kg} \mathrm{milk} / \mathrm{cow} / \mathrm{day}$, respectively. The optimum temperature for treating soybeans to improve protein utilization was also found to be $146^{\circ} \mathrm{C}$ followed by 30 minutes at this temperature before cooling (Faldet et al, 1988, J Nutr, 122, 151).

A lactation study was conducted with optimally heated linted cottonseed $\left(146^{\circ} \mathrm{C}\right.$ - held for 30 $\mathrm{min}$ ). Three groups of cows (14 - 17 per group) were placed on experiment at parturition. Control cows received soybean meal as a protein supplement, and treatment cows received a diet with $15 \%$ linted cottonseed (heated or unheated). Milk production through five weeks of lactation was very similar for all three treatments, but by week 6 the heated cottonseed group appeared to be producing more milk than the other two groups. By the end of week 11 , cumulative milk production averages for the control, unheated and heated cottonseed groups were $38.2,38.1$ and $39.4 \mathrm{~kg} /$ cow $/$ day. 